

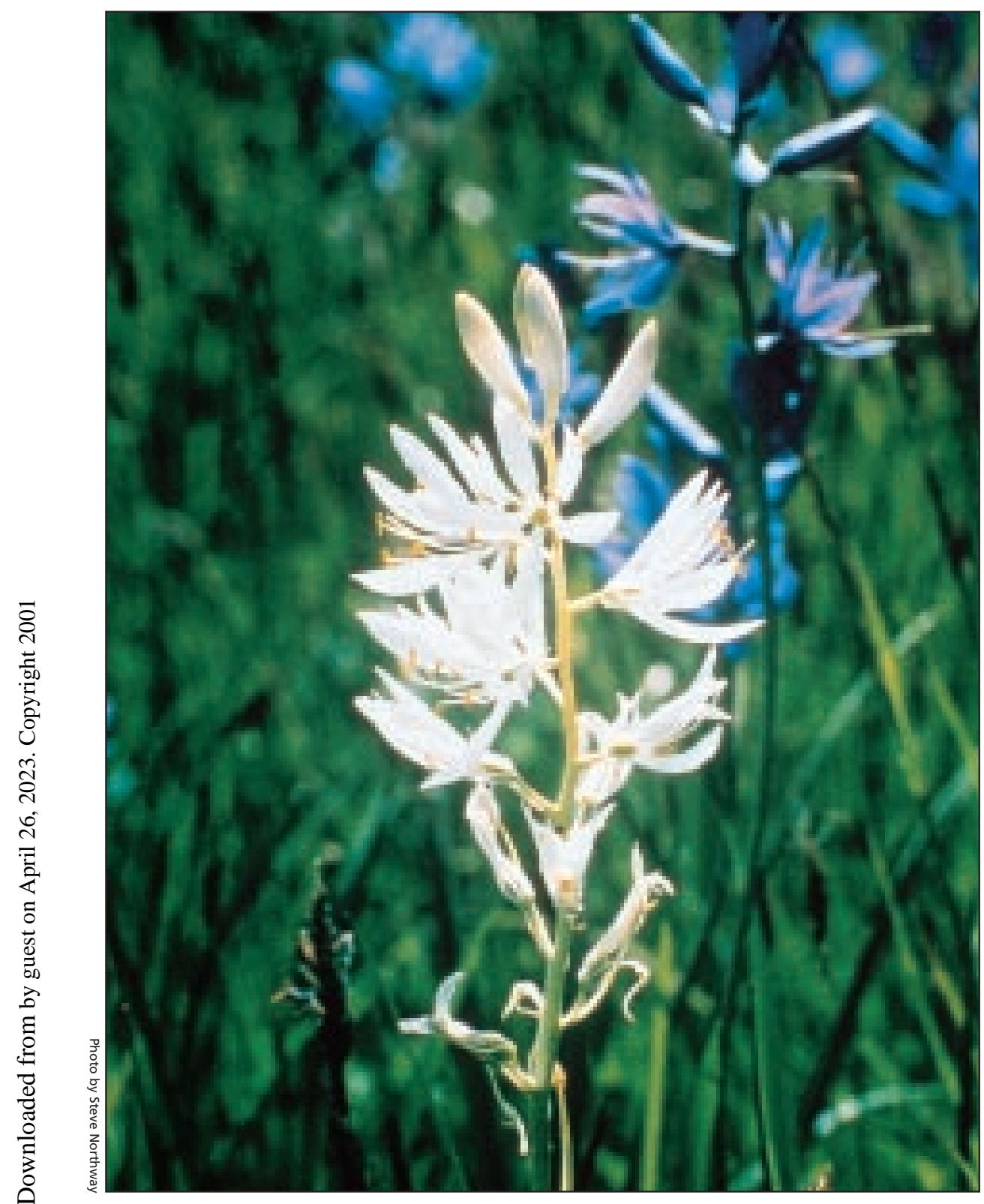

Figure 1 White-flowering Camassia quamash.

to northern California, east to Montana, Wyoming, and Utah. It is found from near sea level to $3300 \mathrm{~m}$ $(10,800 \mathrm{ft})$ in the Rocky Mountains and Sierra Nevada Mountains. Common camas inhabits moist meadows, rocky outcrops, bluffs, and islands in southwestern British and northern Idaho, it occurs in wet prairies and wet meadows, historically very common in the Camas Prairie and the Palouse Prairie. Camas has been used for human food and trade, wildlife food, medicinal purposes, conservation

Montana, and south to California including the Coast Salish of Vancouver Island, Squamish, Sechelt, Comox, Kwak-waka'wakw, Grand Ronde and Kalapuya (or Callapooya) (Kuhnlein and Turner 1991). The bulb of common camas was a very important food and trading material to the Nez Perce of northeastern Oregon, eastern Washington, and northern Idaho. It was also considered to be one of the most important bulbs to northern California native peoples.

Except for choice varieties of dried salmon, no other food item was more widely traded than camas bulbs (Gunther 1973). People traveled great distances to harvest the bulbs and there is some suggestion that plants were dispersed beyond their range by transplanting (Turner and Efrat 1982; Turner and Kuhnlein 1983). To the Nez Perce, camas is still the most important root in trade, and trading is traditionally impossible without camas bulbs (Harbinger 1964). Dried camas is the most expensive form of camas, with baked and then raw camas being less expensive. At marriage trades, the girl's family gives roots in corn husk bags. At funeral trades, camas roots are given to friends and relatives by the widow. The Nez Perce traded camas roots with the Warm Springs, the Umatilla, the Cayuse, the Walla Walla, the Nespelem, the Yakama, the Crows, and the Flatheads.

Common camas does not appear to naturally occur in southcentral British Columbia and the Okanogan region of Washington State. But the native people, the Thompsons, used the dried bulbs as food. The dried bulbs were obtained from the Coastal Salish (Turner and others 1990) or from the Nez Perce (Figure 2).

Bulbs were usually dug after flowering, in summer, although some peoples dug them in spring. Harvesting bulbs traditionally took weeks or months among the Nez Perce. Each family group "owned" its own camping and harvesting spot, and these were passed down in families from generation to generation. Turf was lifted out systematically in small sections and then replaced after only larger 
bulbs were removed. Bulbs were dug with a pointed digging stick; bulbs were broken up and replanted.

Annual controlled burning was used to maintain an open prairie-like habitat for optimum camas production.

Areas were only harvested once every few years.

Traditionally, camas bulbs were almost always pit-cooked; within the past 100 y camas bulbs have also been cooked by stovetop methods (Turner and Kuhnlein 1983). Bulbs are allowed to cook for 24 to $36 \mathrm{~h}$ when pit-cooked (Turner and Bell 1983). It is probable that lengthy cooking is necessary for maximum conversion of inulin to fructose. The sweetness of cooked camas gave it utility as a sweetener and enhancer of other foods. Before sugar, molasses, and honey were introduced by European traders, sweetening agents were in short supply among native peoples, and camas was highly valued in this capacity. Sometimes other foods, such as the rhizomes of springbank clover (Trifolium wormskioldii Lehm. [Fabaceae]) and the roots of Pacific silverweed (Potentilla anserina ssp. pacifica (TJ Howell) Rousi

[Rosaceae]) were cooked with the camas bulbs. The Kalapuya of the Willamette Valley in Oregon flavored camas bulbs with tarweed (Madia spp. Molina [Asteraceae]).

Camas bulbs store poorly fresh. They were cooked or sun-dried and stored for later use. Sometimes camas bulbs were pressed flat and made into camas cakes the size of biscuits before being dried (Turner and Kuhnlein 1983). Dried bulbs were re-constituted by soaking in water, usually overnight.

Many of the traditional camas gathering sites, such as wet prairies of the Palouse Prairie in eastern Washington, Weippe Prairie and Camas Prairie in northern Idaho, and the Willamette Valley in Oregon, have been converted to agriculture. The average size of a camas patch needed to feed a 5 person family was 2.7 ha (6.7 ac) (Thoms 1989). Areas producing camas roots are now hard to find. Restoration of camas prairies and access to camas bulbs are priorities of many Indian people. Once, dense stands dominated many sites in the region. According to the journal of Meriwether Lewis on 12 June 1806, "... the quawmash in now in blume and from the colour of its bloom at a short distance it resembles lakes of fine clear water, so complete is this deseption than on first sight I could have swarn it was water" (Moulton 1983; see Murphey and Van Allen 1959 for a similar description; Figure 3).

Camas stalks and leaves were used for making mattresses. It was sometimes used in place of grass when baking camas in pits. Camas is used by the Nez Perce as a cough medicine. It is boiled, and the juice is strained and mixed with honey. Horticulturally, this plant is used for cut flowers, beds, borders, ground cover, rock gardens, and prairie restoration.

Elk, deer, and moose reportedly graze camas early in the spring (Craighead and others 1963). Gophers eat camas and move the bulbs to another area where they sprout and grow the next year
(Thoms 1989). Indian women in Oregon's Umpqua Valley robbed camas bulbs from gopher caches (Piper 1916). Phytophagus insects also eat camas leaves.

\section{PLANT ESTABLISHMENT}

Common camas can be propagated from seeds or bulbs. Common camas generally prefers full sun to partial shade, with bulb depth ranging from 5 to $20 \mathrm{~cm}$ ( 2 to 8 in) but most commonly 10 to $15 \mathrm{~cm}$ (4 to 6 in). Bulbs of common camas can be substantially smaller in size and occur at shallower soil depths than great camas. Bulb depth appears limited by high water tables, anoxic conditions, or restrictive layers. Plants require moist soil conditions or irrigation to become established.

\section{Bulb Collections}

Common camas is readily established by transplanting wild or commercially grown bulbs. Wild harvests should be restricted to salvage sites with appropriate approvals or permits. Due to loss of wetland habitat throughout the US,

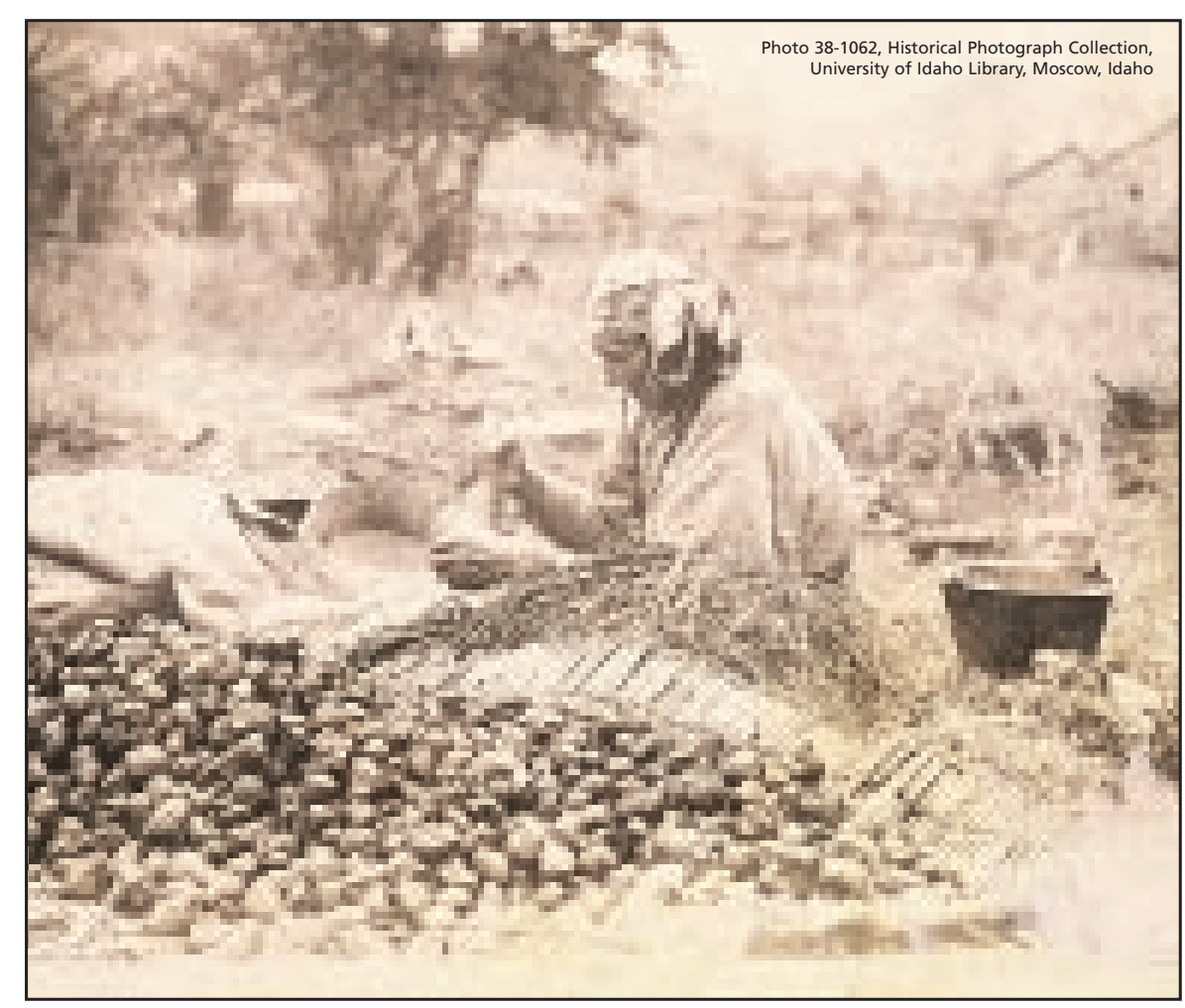

Figure 2 - A Nez Perce woman pounds sun-dried camas bulbs in the Clearwater River country of northern Idaho around 1890. 


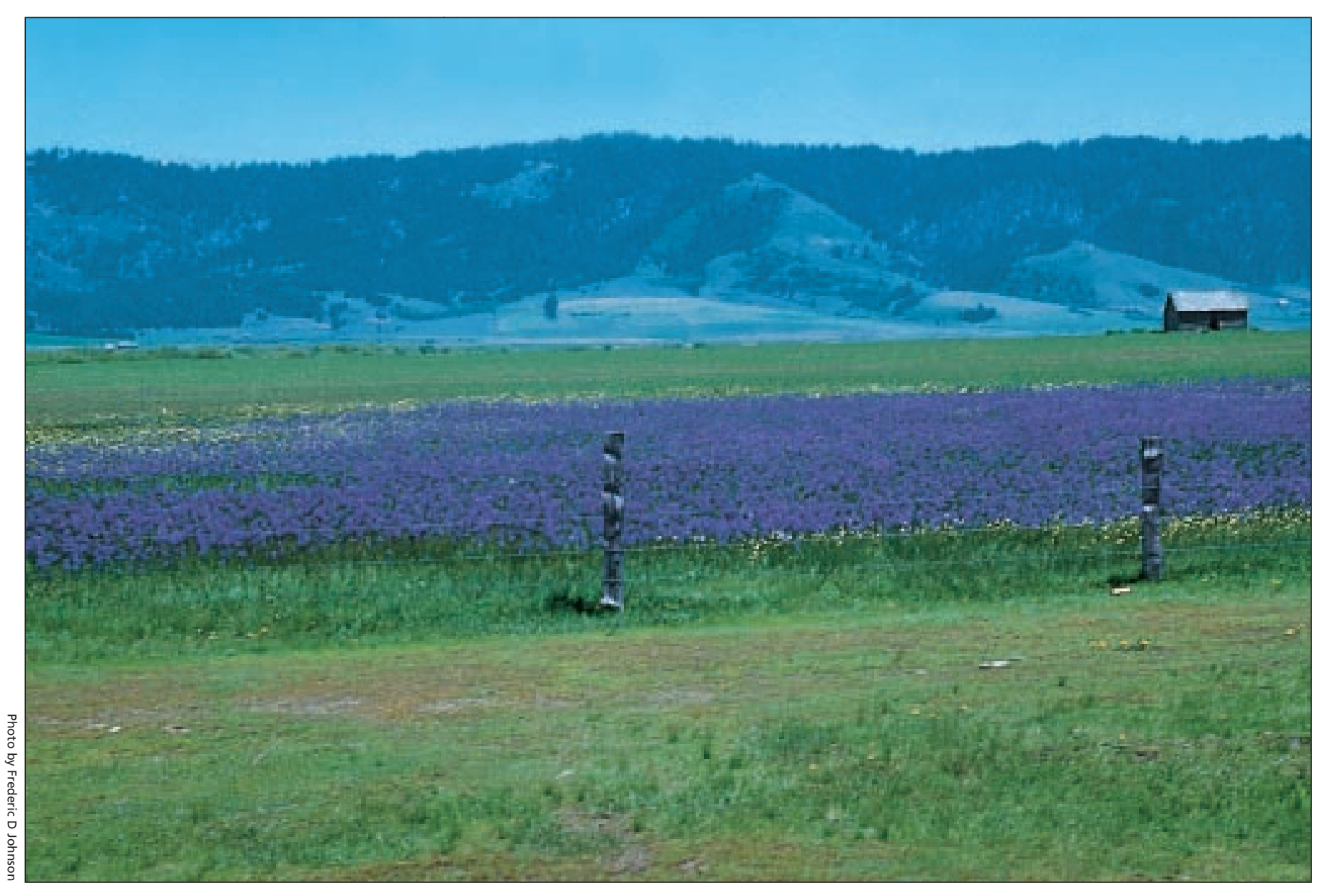

Figure 3 - Camas blooming in an Idaho meadow.

harvesting plants from the wild is rarely appropriate or legal except under salvage situations. Use of bulbs or seeds from local nurseries or greenhouses is strongly recommended.

The best time to excavate bulbs is from early summer through mid-fall. This is the "quiescent" period that follows seed maturation, foliar senescence, and development of the daughter bulb. However, commercial bulb harvest takes place when leaves are still green and must be done carefully to avoid damage. The bulb tunic or covering is very thin (De Hertogh and Le Nard 1993). Given that camas commonly occupies sites high in silt and clay that dry out in summer, windows for digging are often narrow. There is a brief period to harvest bulbs when soils are moist after flowering in the spring; the next time to harvest is in fall after the rains begin.

Store camas bulbs in a dry, dark, cool, well ventilated place in a potting medium such as dry peat moss, similar to recommendations for fall planted or spring flowering bulbs (such as daffodils and tulips). Keep bulbs from completely drying out and transport or store at 17 to $20{ }^{\circ} \mathrm{C}$ (63 to $68^{\circ} \mathrm{F}$ ) (De Hertogh and others 1990). Common camas reproduces vegetatively by offset bulblets (De Hertogh and others 1993). However, much less than $1 \%$ of a wild population may produce offsets and bulbs may be stimulated to do so only as the result of a wound (Thoms 1989).

Plant camas outdoors in the fall or early winter when soils are moist enough to dig and prevailing soil temperatures are cool; this is generally below $16^{\circ} \mathrm{C}\left(60^{\circ} \mathrm{F}\right)$. Fall planting allows for better root development and fulfillment of any chilling requirement for flowering (De Hertogh and others 1993). Bulbs, bulblets, and offsets can be used (Figure 4). However, if flowering is desired the following spring, bulbs must be 3- to 5-y-old and have 3 to 4 bulb leaves or scales (Thoms 1989). Bulb leaves are laminate concentric layers that comprise much of the bulb, reminiscent of an onion. Bulbs with just 2 bulb leaves never flower, those with 3 routinely flower, and those with 4 almost always flower. Older bulbs will be found deeper in the ground, and bulbs that flower will probably be at least 1.5 to $2.0 \mathrm{~cm}(0.6$ to 0.8 in) wide (Thoms 1989). In the commercial bulb trade the minimum size for export and thus flowering is a circumference of $6.0 \mathrm{~cm}$ (2.4 in) (De Hertogh and Le Nard 1993), roughly equivalent to a diameter of $2.0 \mathrm{~cm}$ (0.75 in) and about one-half the diameter and circumference of great camas.

The larger the bulb the greater the planting depth. Planting depth (as measured to the base of the bulb) ranges from 1.2 to $2.5 \mathrm{~cm}(0.5$ to 1 in) for 1 - to 2 -y-old bulblets up to 10 
to $15 \mathrm{~cm}$ ( 4 to 6 in) for mature bulbs. Larger bulbs ( $4 \mathrm{~cm}$ (1.5 in) diameter or greater) can be planted deeper (20 to $25 \mathrm{~cm}$ [8 to $10 \mathrm{in}$ ]) if drainage is appropriate.

Commercial production involves transplanting immature bulbs from October to November in well-drained soil, pH 6 to 7 , with at least $2 \%$ organic matter. Seed is not commonly used. Bulbs are covered with at least $7.5 \mathrm{~cm}$ (3 in) of soil above the bulb's top end, followed by $6 \mathrm{~cm}$ (2 in) of straw mulch. Four weeks after planting a $7 \mathrm{~N}: 14 \mathrm{P}_{2} \mathrm{O}_{5}: 28 \mathrm{~K}_{2} \mathrm{O}$ fertilizer is applied (presumably top-dressed). The camas bed is kept damp, but once plants become senescent after flowering, watering is discontinued. By this time, seeds have formed and bulbs are curing. Camas bulbs are harvested in late July (De Hertogh and others 1990). No serious insect pests are reported, but diseases include the fungus Rhizoctonia tuliparum (Kleb.) Whetzel \& J.M.

Arthur and nematodes in the genus Ditylenchus Filipjev (Anguinidae)(De Hertogh and others 1990). Some pest control is done by immersion of bulbs in a hot water treatment for $4 \mathrm{~h}$ at 43.5 to $45^{\circ} \mathrm{C}$ (110 to $\left.113^{\circ} \mathrm{F}\right)$. Another pest is a mosaic virus (De Hertogh and Le Nard 1993).

Suggested spacing for bulbs in flower beds and naturalized landscapes varies from 7.5 to $10 \mathrm{~cm}$ (3 to $4 \mathrm{in})$ apart (85 to $105 / \mathrm{m}^{2}$ [ 8 to $10 / \mathrm{ft}^{2}$ ]) to 15 to $20 \mathrm{~cm}$ (6 to 8 in) apart (Bryan 1989). Others recommend 6 to 8 bulbs every $30 \mathrm{~cm}$ (12 in) for outdoor gardens (Brenzel 1995; Kruckeberg 1996). A dense "natural" stand may have 100 plants per $\mathrm{m}^{2}\left(9 / \mathrm{ft}^{2}\right)$ or more (Thoms 1989). It may be nec- essary to bury bulbs with a protective wire mesh to prevent herbivore damage; the mesh needs to be coarse enough to allow shoots to grow through (De Hertogh and others 1993).

\section{Seed Collections}

Common camas propagates easily from seeds. It can be collected as soon as the pods mature (turn light brown) or split open to reveal the mature black seeds. Pods ripen from late May to July depending on latitude, longitude, moisture conditions, and elevation. Dry seeds can be stored frozen or in a cool, dry place prior to planting (Watson 1988). We estimate $287,000( \pm 66,000)$ seeds per $\mathrm{kg}(130,000 \pm 30,000 / \mathrm{lb})$ for Camassia quamash ssp. breviflora Gould.

Camas seed requires 42 to $100 \mathrm{~d}$ of cold, moist stratification $\left(1\right.$ to $4{ }^{\circ} \mathrm{C}$ [34 to $40{ }^{\circ} \mathrm{F}$ ]) for maximum germination $(90 \%$ to $100 \%)$ (Emery 1988 ; Thoms 1989; Deno 1993; Guerrant and Raven 1995; Northway 1998). "Moist stratification" means placement of dry seeds in layers of a moist medium at cool temperatures to allow for moisture uptake and to break seed dor- mancy. Germination itself also requires cool conditions and can occur in the dark (Northway 1998). An alternative is to plant seed outdoors in the fall (September to October). One-leafed, grass-like seedlings will emerge in February or March under suitable conditions where winters are comparatively mild. Germination occurs in early May in Montana or at $4{ }^{\circ} \mathrm{C}\left(40{ }^{\circ} \mathrm{F}\right)$ (Wick and Evans 2000). Seedlings require moisture through the spring growing period to survive. Warm temperatures during seedling development can be lethal.

Suggested site preparation methods and seeding rates for wetland revegetation are not well known, but in at least 1 unpublished study an estimated seeding rate was determined (Darris, unpublished data). At the Corvallis Plant Materials Center in Oregon, Darris used a broadcast rate of 210 live seeds per $\mathrm{m}^{2}\left(20 / \mathrm{ft}^{2}\right)$ for both Camassia subspecies and found poor to good seedling counts the following spring $\left(0\right.$ to $>105$ per $\mathrm{m}^{2}\left[0\right.$ to $\left.>10 / \mathrm{ft}^{2}\right]$ ). Seedling success was dependent on weed competition, hydrology, type of

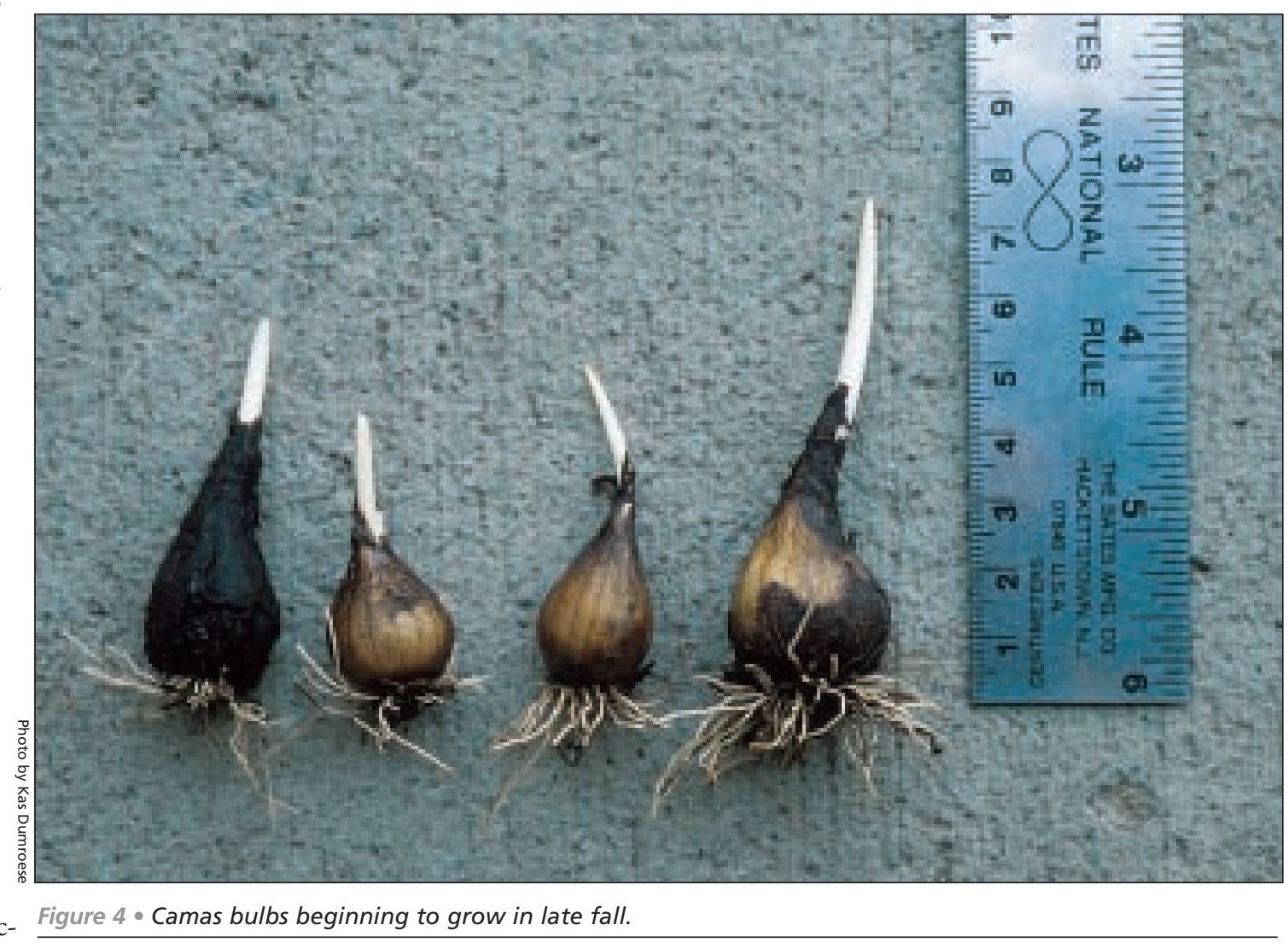


disturbance, mulch, erosion, or other factors. Camas seedling establishment appeared inhibited by dense stands of perennial ryegrass (Lolium multiflorum Lam. [Festuceae]) but benefited from a thin mulch (straw) of tufted hairgrass (Deschampsia cespitosa (L.) Beauv.

[Festuceae]) and less plant competition, at least on well-drained, stable, slightly higher ground.

In areas with wet, mild winters, soil scarification for shallow seed coverage or just constant moisture from irrigation or winter rains can result in good germination. At least 1 western Oregon grower sows seeds directly on the soil surface in fall (Robinson 1999). However, growers in Idaho have found that a $2.5-$ to $5-\mathrm{cm}$ (1- to 2-in) covering of organic mulch is required during the first growing season to protect the tiny bulblet from exposure to dry soil, surface cracking, and extreme temperatures. Sawdust or a chemically killed dense stand of grass works well (Watson 1999). Seeds buried deeper than 1 to $2 \mathrm{~cm}$ ( 0.4 to 0.8 in) will not germinate successfully (Watson 1988).

\section{MANAGEMENT}

Traditional resource management of common camas was often intensive, to the point of being considered "semiagricultural” by some authors. Cultural management of common camas was used by Native Americans to maintain, increase, and enhance their camas areas. According to Turner and others (1990), traditional resource management included: 1) ownership, demarcation, and inheritance of beds or patches that were maintained by individuals or families; 2) clearing camas areas of rock, brush, and weedy vegetation for improved bulb production and easier harvest; 3) harvesting bulbs after seeds were set; 4) periodically burning camas fields in summer after bulb harvest; 5) sometimes removing or lifting overlying sod where camas grew with other herbaceous plants so bulbs could be harvested; after harvesting the sod was replaced; 6) digging or "cultivation" of the camas area to keep the soil loose; 7) "selective breeding" by transplanting "better" bulbs to camas areas; 8) sustainable harvest techniques using digging sticks or other implements; digging techniques included partial, selective harvesting, and incidental or planned promotion of camas colonization and reproduction; 9) removal of death camas bulbs from growing areas so they would not accidentally be mistaken for the edible camas bulbs.

Camas is favored as forage by deer and other wildlife species, so fencing or repellents may be a useful tool, especially important during the first growing season. Consistent soil moisture is required every spring, but the soil can be allowed to dry out soon after the pods mature or the leaves senesce (dry up and turn brown) in early summer. Moderate soil nutrient levels are beneficial. In natural settings, minor soil disturbance (loosening, surface scarification) adjacent to existing specimens may enhance natural regeneration by seeds. Late summer field burning (where and when permitted) may improve stand vigor, reduce competi-

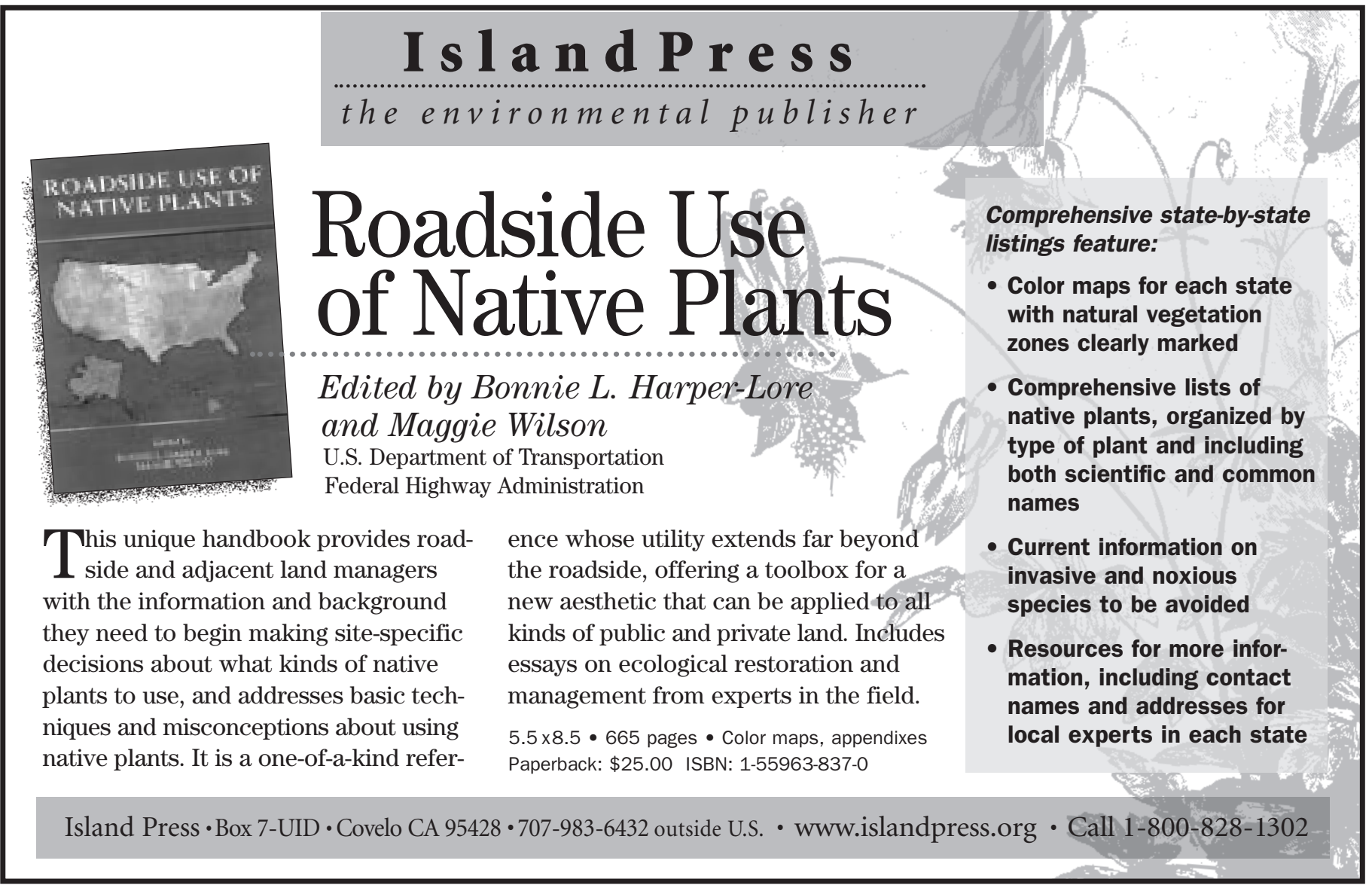


tion from brush and certain weeds, and aid in regeneration. For optimal bulb development, avoid mowing or grazing more than lightly, if at all, even during foliar senescence. Individual plants may live 15 to $20 \mathrm{y}$.

\section{REFERENCES}

Brenzel KN, editor. 1995. Sunset western garden book. Menlo Park (CA): Sunset Publishing Corporation. $512 \mathrm{p}$.

Bryan J. 1989. Bulbs. Portland (OR): Timber Press. $430 \mathrm{p}$.

Craighead JJ, Craighead FC, Davis RJ. 1963. A field guide to Rocky Mountain wildflowers. Boston (MA): Houghton Mifflin Company.

Deno NC. 1993. Seed germination theory and practice. State College (PA): self-published and self-distributed. p 110.

De Hertogh AA, Le Nard M. 1993. Chapter 37, general chapter on spring flowering bulbs. In: DeHertogh AA, Le Nard, editors. The physiology of flower bulbs. New York (NY): Elsevier Science Publishing Co. 734 p.

De Hertogh AA, Noone C, Lutman A. 1990. Camassia. In: Geophyte, Version 2.2. Raleigh (NC): North Carolina State University, Department of Horticultural Science. $8 \mathrm{p}$.

De Hertogh AA, Gallitano LB, Pemberton GH, Traer ME. 1993. Guidelines for the utilization of flowering bulbs as perennial (naturalized) plants in North American landscapes and gardens. Hillegom, Netherlands: Holland flowe bulb technical services, Netherlands Flower Bulb Center (IBC). Bulletin No. 37.

Emery DE. 1988. Seed propagation of native California plants. Santa Barbara (CA): Santa Barbara Botanic Garden.

Farr DF, Bills GF, Chamursi GP, Rossman AY. 1989. Fungi on plants and plant products in the United States. St Paul (MN): The American Phytopathological Society Press. $1252 \mathrm{p}$.

Guerrant EO Jr, Raven A. 1995. Seed germination and storability studies of 69 plant taxa native to the Willamette Valley wet prairie. Portland (OR): The Berry Botanic Garden. 65 p.

Gunther E. 1973. Ethnobotany of western Washington. Seattle (WA): University of Washington Press. Seattle University of Washington Publications in Anthropology 10(1).

Harbinger $\sqcup .1964$. The importance of food plants in the maintenance of Nez Perce cultural identity [MSc thesis]. Pullman (WA): Washington State University. $82 \mathrm{p}$.

Hitchcock CL, Cronquist A. 1973. Flora of the Pacific Northwest. An illustrated manual. Seattle (WA): University of Washington Press. $730 \mathrm{p}$.

Hitchcock CL, Cronquist A, Ownbey M, Thompson JW. 1969. Vascular plants of the Pacific Northwest: part 1. Seattle (WA): University of Washington Press. 914 p.

[ITIS] Integrated Taxonomic Information System. 2000. Biological names. Version 4.0 [on-line database]. URL: http://www.itis.usda.gov/plantproj/itis/itis-query.html (accessed 7 Nov 2000).

Kruckeberg AR. 1996. Gardening with native plants of the Pacific Northwest, 2nd edition. Vancouver (BC): Greystone Books/Douglas and McIntyre and University of Washington Press. $282 \mathrm{p}$

Kuhnlein HV, Turner NJ. 1991. Traditional plant

foods of Canadian indigenous peoples.

Nutrition, botany, and use. Vancouver (BC):

Gordon and Breach Science Publishers. $633 \mathrm{p}$.

Moulton GE, editor. 1983. The journals of the

Lewis and Clark expedition. Volume 8, June 10

- September 26, 1806. Lincoln (NE): University

of Nebraska Press.

Murphey E, Van Allen V. 1959. Indian uses of

native plants. Ukiah (CA)

Mendocino County Historical

Society. 81 p.

Northway S. 1998. Personal communication. Corvallis (OR): Oregon Native Plant Society.

Piper CV. 1916. Notes on Quamasia with a description of a new species. Proceedings of the Biological Society of Washington 24:77.

Robinson R. 1999. Personal communication. Lorane (OR): Balance Restoration Nursery.

Thoms A. 1989. The northern roots of hunter-gatherer intensification: camas and the Pacific Northwest [dissertation]. Pullman (WA): Washington State University. $521 \mathrm{p}$

\section{OTHER CAMAS REFERENCES}

Guard JB. 1995. Wetland plants of Oregon and Washington. Redmond (WA): Lone Pine Publishing. 239 p.

Pojar J, MacKinnon A. 1994. Plants of the Pacific Northwest coast: Washington, Oregon, British Columbia and Alaska. Redmond (WA): Lone Pine Publishing and the British Columbia Ministry of Forests $527 \mathrm{p}$.

Turner NJ, Bell MAM. 1983. The ethnobotany of the southern Kwakiutl Indians of British Columbia. Econonomic Botany 27:257-310.

Turner NJ, Efrat BS. 1982. The ethnobotany of the Hesquiat Indians of Vancouver Island. Victoria (BC): British Columbia Provincial Museum. Cultural Recovery Paper No. 2.

Turner NJ, Kuhnlein HV. 1983. Camas (Camassia spp.) and riceroot (Fritillaria spp.): two Liliaceous "root" foods of the Northwest Coast Indians. Ecology of Food and Nutrition 13:199-219.

Turner NJ, Thompson LC, Thompson MT, York AZ. 1990. Thompson ethnobotany: knowledge and usage of plants by the Thompson Indians of British Columbia. Victoria (BC): Royal British Columbia Museum. Memoir No. 3. $335 \mathrm{p}$.

USDA NRCS. 1999. The PLANTS database, Version 3.0. URL: http://plants. usda.gov/plants (accessed 30 Oct 2000). Baton Rouge (LA): National Plant Data Center.

Watson RD. 1999. Personal communication. Moscow, Idaho.

Wick D, Evans J. 2000. Propagation protocol for container Camassia quamash (Pursh) Greene ssp. qua-

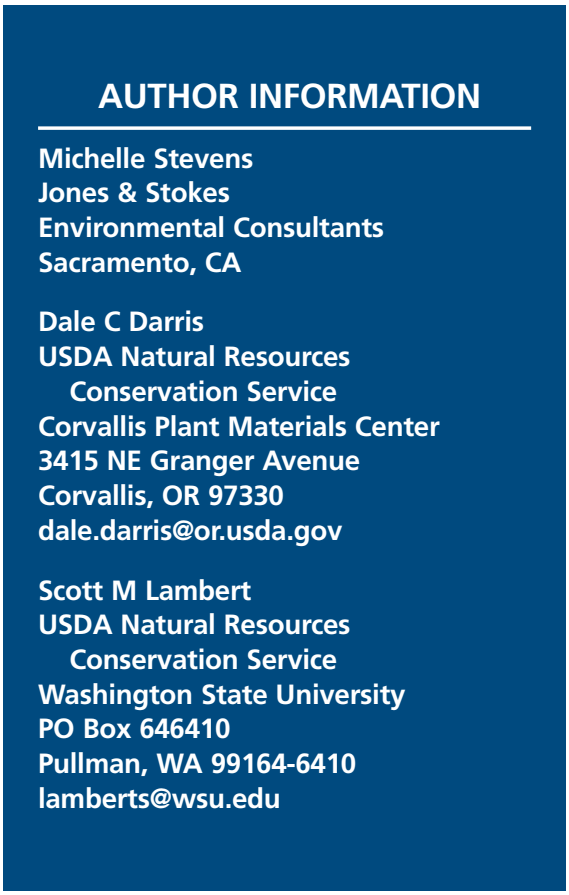
mash plants (164 $\mathrm{ml}\left(10 \mathrm{in}^{3}\right.$ ) Leach Cone-tainers) Glacier National Park, West Glacier, Montana. In: Native Plant Network. URL: http://nativeplants.for uidaho.edu (accessed 30 Oct 2000). Moscow (ID): University of Idaho, College of Natural Resources, Forest Research Nursery. 